\title{
Isolation and virtual screening of antimicrobial prodigiosin pigment from oxalotrophic Serratia marcescens $\mathrm{OX}$ _R strain
}

\author{
Mangesh V. Suryavanshi ${ }^{1 *}$, Samadhan R. Waghmode ${ }^{2}$, Nidhi Bharti ${ }^{3}$, Prafulla B. Choudhari ${ }^{4}$, Tejashri B. Hingamire ${ }^{5}$, \\ Yogesh S. Shouche ${ }^{1}$ \\ ${ }^{1}$ Microbial Culture Collection, National Centre for Cell Science, Pashan, Pune -411021 , India. ${ }^{2}$ Department of Microbiology, Elphinstone College, Fort, \\ Mumbai - 400 032, India. ${ }^{3}$ Department of Botany, Savitribai Phule Pune University, Pune -411007 , India. ${ }^{4}$ Department of Pharmaceutical Chemistry, \\ Bharati Vidyapeeth College of Pharmacy, Kolhapur 416013, India. ${ }^{5}$ Biochemical Division, National Chemical Laboratory, Pune 411008 , India.
}

\section{ARTICLE INFO}

Article history:

Received on: 27/05/2016

Revised on: 12/07/2016

Accepted on: 09/08/2016

Available online: 29/11/2016

Key words:

Oxalotrophic; Serratia

marcescens; prodigiosin;

natural dyeing agent.

\begin{abstract}
Prodigiosin a multifaceted secondary metabolite produced by Serratia spp. having great potential as a pharmaceutical. In the present study we demonstrate that oxalate supplementation in peptone glycerol production media increased organoleptic characters and yield of prodigiosin pigment extracted from oxalotrophic Serratia marcescens OX_R isolated from Indian bat guano sample. The pigment was demonstrated in-vitro as an antibacterial agent against common opportunistic skin surface pathogen Staphylococcus aureus NCIM 5021 strain as killing activity by agar well diffusion method. The docking analysis and pharmacophore modelling indicated that the probable mechanism of action of the prodigiosin was against Staphylococcus aureus DNA gyrase protein. The pigment was also found to efficiently dye both cotton and latex polymer. In summary, we describe here an oxalotrophic Serratia marcescens which may serve as a potent and economical resource of prodigiosin which owing to its dyeing and anti-bacterial activities finds future avenues to be developed as dressing material for nosocomial subjects or burn victim patients.
\end{abstract}

\section{INTRODUCTION}

Bacterial secondary metabolites have found applications as potent enzymes, pigments and antibiotics and are being produced on large industrial scales. Prodigiosin (red pigment) is one of the secondary metabolites produced by Serratia marcescens and several other bacterial species such as Vibrio psychroerythrus (D'Aoust and Gerber 1975), Pseudomonas magnesiorubra (Lewis and Corpe 1964), Alteromonas rubra, Actinomycetes such as Streptomyces spp. and Nocardia spp. (Khanafari et al., 2006). It has a tripyrrole structure which was first characterized from Serratia marcescens

\footnotetext{
* Corresponding Author

Mangesh V. Suryavanshi, Microbial Culture Collection, National Centre for Cell Science, Pashan, Pune - 411021, India. Tel: +91-20-25329000 Fax: +91-20-25692259; Email: mangeshnccs@gmail.com
}

and was shown to be localized in extracellular and cell associated vesicles and in intracellular granules (Kobayashi and Ichikawa 1991). The pigment absorbs light at defined wavelength $535 \mathrm{~nm}$ and its expression can be monitored spectrometrically with relative ease (Haddix and Werner 2000). Alihosseini et al. (2008), generated large quantities of the pigment form Vibrio spp. isolated from marine sediments which was later used as a clothing dye. The production of prodigiosin by Serratia marcescens is dependent on temperature and is significantly reduced at temperatures higher than $37^{\circ} \mathrm{C}$ (Giri et al., 2004) optimized the growth of Serratia using a variety of media and they observed that a novel peanut seed broth resulted in significant enhancement of prodigiosin production. Prodigiosin possesses antibacterial, antifungal (Gulani et al., 2012), antiprotozoal (Croft et al., 2003), cytotoxic (Nakashima et al., 2005) antitumor (Pérez-Tomás et al. 2003; Chang et al. 2011), antimalarial (Isaka et al. 2002; Patil et al., 2011) and anti-cancerous properties (Ho et al., 2009). 
Hence it has a huge potential for commercial applications, which would need a cost effective bioprocesses for its production. With the event of multi-facilitated potency description of prodigiosin pigment, proposals for newer combinatorial drugs are being evolved which include in vitro assays for antibacterial (Lapenda et al., 2015), anticancer (Hassankhani et al., 2015) and in-silico assays for antiinflammation activities (Krishna et al., 2013). Production of bioactive secondary metabolites by microorganisms is extensively governed by factors like species and strains of microorganisms, specific nutrient requirements, and growth conditions (Wang et al., 2012).. Even trifling modifications in the growth or fermentation media composition can significantly alter the quantity as well as quality of the secondary metabolite production by microorganisms (Wang et al., 2012). Hence, prior to large scale production of beneficial secondary metabolites, optimization of the fermentation medium is quintessential to devise methods corresponding to low input cost and higher outputs in terms of yield and quality (Narendra Kumar et al., 2015). Keeping in view, the scope of applications of prodigiosin and the need for optimization of production methods, the present study attempts to identify and optimize less intensive methods for better yield of prodigiosin. We hypothesise that presence of oxalate in production media improves prodigiosin yield in an oxalotrophic Serratia marcescens isolated from bat guano samples. The isolated prodigiosin also demonstrates affinity towards binding with the protein DNA gyrase of bacterial origin. In the present study we demonstrate through analytical techniques viz., NMR, Mass and IR spectroscopy that oxalate augments prodigiosin yield, when added exogenously in the medium. Further, the potential of prodigiosin as an efficient antimicrobial agent was illustrated through in vitro antimicrobial susceptibility assay and its affinity to bind with the DNA gyrase through docking analysis.

\section{MATERIAL AND METHODS}

\section{Isolation and identification of oxalotrophic Serratia spp.}

Isolation of oxalotrophic Serratia was carried out from bat guano sample collected from Robbers' Cave Mahabaleshwar, Satara, India $\left(17.9217^{\circ} \mathrm{N}, 73.6556^{\circ} \mathrm{E}\right)$. For isolation of oxalotropic bacteria, bat guano sample was enriched with oxalate following the method of Sahin (Sahin etl al., 2004) with slight modifications as follows $200 \mathrm{mg}$ of guano inoculated in $50 \mathrm{ml}$ nutrient broth supplemented with $0.5 \%$ sodium oxalate. After incubation at $28{ }^{\circ} \mathrm{C}$, for $72 \mathrm{hr}, 0.1 \mathrm{ml}$ of sample was spread on Schegels Mineral agar plate, supplemented with $200 \mathrm{mM}$ sodium oxalate and calcium chloride (1 $\left.\mathrm{g} \mathrm{L}^{-1}\right)$ (Bravo et . al., 2011). A clear zone was found after $24 \mathrm{hr}$ incubation surrounding the colonies indicating that the addition of sodium oxalate and calcium chloride produces calcium oxalate precipitate, which can be degraded by bacteria. Pure cultures of the positive isolate (OX_R) were obtained. To identify the oxalate positive isolate OX_R, morphological characterization, 16S rRNA gene sequencing and assessment of production of cell associated reddish pigment were performed. Genomic DNA from OX_R strain was isolated, 16S rRNA gene sequencing and phylogenetic analysis of derived sequence was carried out as method described earlier (Gupta et al., 2011). Based on the analysis, the strain OX_R was identified to be Serratia marcescens.

\section{Production and recovery of prodigiosin pigment}

Pigment production was carried out from oxalotrophic bacteria using peptone glycerol broth. Production media was supplemented with $200 \mathrm{mM} \mathrm{L}^{-1}$ of sodium oxalate (Sigma Aldrich). In lab scale fermenter (5L capacity), production (3L) media was added and sterilized by autoclave. A 5\% overnight growing culture of Serratia marcescens $\mathrm{OX} \_\mathrm{R}$ strain $\left(\mathrm{OD}_{620 \mathrm{~nm}}\right.$ 0.6) was used as an inoculum in the fermenter experiment. During the fermentation process the agitation speed was maintained at 100 rpm and aeration was supplied for 5 days. After the completion of fermentation, the agitators and aerators were stopped. The pigment was allowed to settle down overnight in the fermenter. The settled mass was then carefully removed from the fermenter and used for extraction.

Prodigiosin is an intracellular pigment. Thus to obtain pigment, medium containing Serratia marcescens OX_R strain was centrifuged at $2000 \mathrm{rpm}$ for 30 minutes. After centrifugation, pellet was dissolved and mixed properly in $5 \mathrm{~mL}$ ethanol and centrifuged at $2000 \mathrm{rpm}$ for 30 minutes. The supernatant was carefully collected in a sterile petri dish and left overnight at the room temperature in order to evaporate the solvent and get the powder form of the pigment.

Pigment was purified by silica gel column chromatography in order to separate out the non-coloured impurities. The solvent system containing 2.5:2.5:0.5 (v/v) of dichloromethane, chloroform and acetone was used. The eluted pigment bulk was further purified by HPLC method. HPLC measurements were performed isocratically at a flow rate of 100 $\mu \mathrm{l} / \mathrm{min}$ using the mobile phase methanol, acetonitrile in $0.2 \%$ acetic acid containing 50:50 (v/v). Pigment absorbance was measured at $523 \mathrm{~nm}$ with UV diode detector. The collected fractions were confirmed as a Prodigiosin by a method described earlier (Gerber et al. 1976).

\section{Confirmation of prodigiosin pigment structure}

The isolated prodigiosin was characterized by the NMR, IR, and Mass spectroscopic analysis. For 1H NMR analysis, prodidiosin was dissolved in DMSO solvent and tetramethylsilane used as an internal standard. Analysis was performed on BruckerAvance $300 \mathrm{MHz}$, NMR spectrophotometer (Brucker Corporation, CA). Infra-red spectra were recorded on Perkin Elmer 1310 FT-IR spectrometer with $\mathrm{KBr}$ pellets. LC-MS analysis was performed on Mass spectrometer API 5500 Qtrap (Applied biosystems, Canada).

\section{In-vitro natural potentials of prodigiosin pigment Dyeing potency}

The dyeing potential of the prodigiosin was checked on the cotton as well as on latex materials using concentration $100 \mu \mathrm{g}$ 
$\mathrm{ml}^{-1}$ solutions. To find out the dyeing efficiency of prodigiosin, the cotton and latex materials was subjected to rigorous washing treatments with hot water and detergents for several hours.

\section{Antimicrobial potency}

To demonstrate antimicrobial activity of the pigment, we tested the pigment against the most common opportunistic skin pathogen by in-vitro conditions. For determining minimum inhibitory concentration (MIC) of yielded pigment as well as standard tetracycline followed the modified procedure described earlier (Suryavanshi et al., 2014) Briefly, each test-tubes of similar size containing with $8.9 \mathrm{ml}$ of sterile nutrient medium was used. One hundred micro-litre amount of test inoculum culture of Staphylococcus aureus NCIM $5021\left(\mathrm{OD}_{620 \mathrm{~nm}} \sim 0.6\right)$ was added in test tubes in a sterile area. One $\mathrm{ml}$ solutions of purified pigment added at such concentrations $0.5,1.0,1.5,2.0,2.5,3.0,3.5,4.0$, 4.5 and $5.0 \mu \mathrm{g} \mathrm{ml}^{-1}$ were attended in these test tubes in triplicates. A similar set of three test tubes was created for standard tetracycline with $0.1,0.2,0.3,0.4,0.5,0.6,0.7,0.8,0.9$ and $1.0 \mu \mathrm{g}$ $\mathrm{ml}^{-1}$ in triplicate manner and with the reagent control. The tubes containing the test specimen were observed for growth by turbidimetric assay. The minimum concentration at which growth was observed to be inhibited was considered as minimum inhibitory concentration (MIC). The antimicrobial activity of prodigiosin against Staphylococcus aureus NCIM 5021 was determined by agar well diffusion assay whereas tetracycline used as standard antibiotic for performing standard regression curve using at $20,40,60,80,100$ and $120 \mu \mathrm{g} \mathrm{ml}^{-1}$ concentrations.

\section{In-silico screening analysis Ligand preparation}

The structure of prodigiosin was used as the template to build the molecules in the dataset in builder module of V life MDS 4.3. The ligands were optimized by energy minimization using Merck molecular force field till a gradient of $0.001 \mathrm{kcal} / \mathrm{mol} / \mathrm{A}^{\circ}$ was reached, maintaining the template structure rigid during the minimization.

\section{Docking studies and pharmacophore modelling}

Docking simulations was carried out using Biopredicta module of Vlife MDS 4.3 using crystal structure of Staphylococcus aureus DNA gyrase (PDB ID 2XCS) downloaded from rcsb.org. The protein structure was first optimized using biopredicta module of Vlife MDS 4.3 where the water molecules from the protein structure was removed and hydrogen's were added this structure was energy minimized using Merck molecular force field till a gradient of $0.001 \mathrm{kcal} / \mathrm{mol} / \mathrm{A}$. This energy minimized structure was further utilized for the docking simulations. Pharmacophore modelling was also carried out in Vlife MDS 4.3 using Mol sign module. The minimum number of pharmacophore features generated for an alignment is taken 4 and tolerance was kept to $10 \AA$.

\section{RESULTS AND DISCUSSION}

\section{Oxalotrophic Serratia spp OX_R strain as a prodiogiosin producer}

The OX_R culture which showed oxalate utilization ability by means of a clear solubilization zone around colony was used for pigment production. The oxalotrophic, bright red pigment producer, was identified by $16 \mathrm{~S}$ rRNA gene sequencing found to be from the Serratia spp. (Fig. 1).

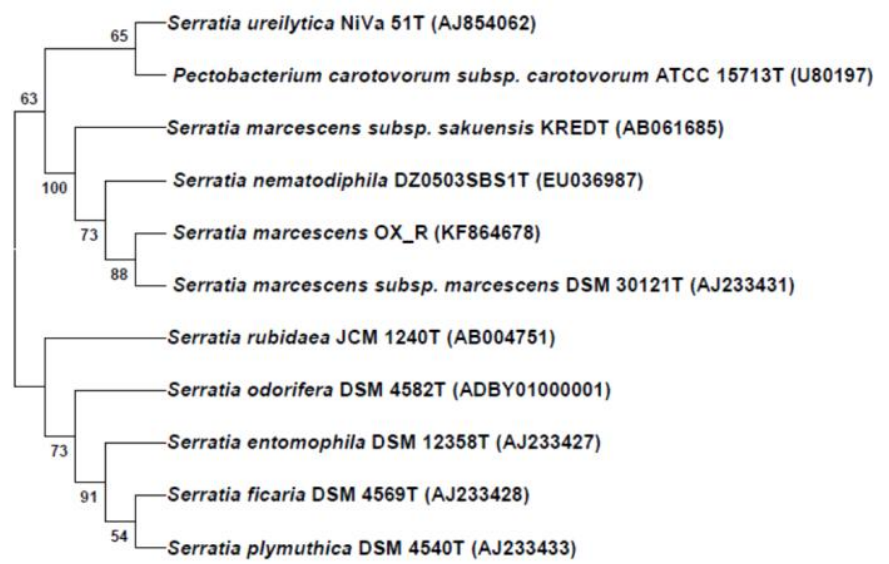

Fig. 1: Dendogram of oxalotrophic Serratia marcescens OX_R strain showing its phylogenic position. The tree was constructed with 1370 bases of the $16 \mathrm{~S}$ rRNA gene by using a neighbor-joining tree method with the Kimura 2 parameter and a 1000 bootstrap for the confidence level.

For phylogeny construction type strains sequences having more than $99 \%$ sequence similarity, downloaded from Eztaxon server at http://www.ezbiocloud.net/eztaxon. Isolated bacterium was observed to be closely related to the Serratia marcescens subsp. marcescens DSM 30121 strain. The 16S rRNA gene sequences were submitted to GeneBank (NCBI) with accession number KF864678. Serratia spp. have oxalate metabolising ability (Bhadra et al. 2006) and oxalate degradation pathways as documented in BioCyc Database Collection at http://biocyc.org. Recent report has indicated that addition of maltose, peanut or sesame seeds to growth medium of Serratia marcescens can induce higher yields of prodigiosin (Shahitha et al., 2012). The present study illustrates that oxalotrophic Serratia marcescens OX_R can be a potent source of prodigiosin.

\section{Quantification, purification and chemical characterization of prodigiosin}

Prodigiosin yield was recorded to be $2.36 \mathrm{mg} / \mathrm{ml}$ in peptone glycerol broth as well as organoleptic properties of pigment produced were notably high in oxalate rich medium. Production of pigment in fermenter (5L capacity) was carried out in replicates whereas another fermenter supplemented without oxalate. Enhanced production of pigment was observed in oxalate amended medium (Table 1). After fermentation, fermented broth with oxalate was subjected for biomass isolation; extraction of 
pigment purification of pigment was carried out by silica gel column chromatography. The compound was further purified by high-performance liquid chromatography (HPLC) (Fig. 2).

The molecular mass of recovered compound was found to be $\mathrm{m} / \mathrm{z} 325[\mathrm{M}]^{+}$. The pigment was further analyzed by UV spectrometer, absorbance observed at $549 \mathrm{~nm}$ (Fig. 3). The isolated pigment is further identified by the NMR, IR and Mass spectrometry which gave characteristic absorption spectra similar to previously reported prodigiosin, which confirmed that the isolated pigment was prodigiosin (Table 2).

Comparative studies reported in Table 1 reflect impact of the raw material used for the production of pigment through fermentation by Serratia spp. whereas the nitrogen supplementation imparts the major role in yield generation (Suryawanshi et al. 2014). Our spectral results are comparable with the previous study (Jenkins et al., 2009) on prodigiosin and confirm its characteristic tripyrrole base indicating that the prodigiosin obtained is not modified in the presence of oxalates. The present study finds limitation in understanding the exact role of oxalate supplementation in subsequent increase in organoleptic characteristic as well as in production yield. However, oxalate has been recorded to promote L-asparginase synthesis (Sukumaran et $a l ., 1979)$ and the formation of amino acid anhydrides of oxalyl compounds (Worthington et al. 1962) in host bacterium which may in turn play some role in enhanced production of prodigiosin.

Table 1: Comparison of prodigiosin like pigment production by different studies.

\begin{tabular}{|c|c|c|c|}
\hline Strains & Media types & Prodigiosin yield (mg/ml) & Refs \\
\hline$\overline{\text { Serratia sp. OX_R }}$ & Peptone glycerol broth with $0.5 \%$ sodium oxalate & $2.36^{*}$ & This study \\
\hline Serratia sp. OX_R & Peptone glycerol broth & $1.14 *$ & This study \\
\hline Serratia marcescens TKU011 & Peanut powder & 1.17 & (Wang et al., 2012) \\
\hline Serratia marcescens TKU011 & Squid Pen Powder & 0.98 & (Wang et al., 2012) \\
\hline Serratia marcescens $\mathrm{SM} \Delta \mathrm{R}$ & Modified LB broth with $6 \%$ sunflower oil & 0.80 & (Wei and Chen, 2005) \\
\hline Serratia marcescens & Nutrient broth & 0.52 & (Giri et al., 2004) \\
\hline Serratia marcescens & Peptone glycerol broth & 0.30 & (Giri et al., 2004) \\
\hline Serratia marcescens & Peanut oil broth & 2.89 & (Giri et al., 2004) \\
\hline Serratia marcescens & Coconut oil broth & 1.42 & (Giri et al., 2004) \\
\hline Serratia marcescens & Sesame oil broth & 1.01 & (Giri et al., 2004) \\
\hline Serratia marcescens & Peanut seed & 38.75 & (Giri et al., 2004) \\
\hline Serratia marcescens & Sesame seed & 16.68 & (Giri et al., 2004) \\
\hline
\end{tabular}

Table 2: Spectral characterization data of isolated prodigiosin.

\begin{tabular}{|c|c|c|c|c|}
\hline Sr. no. & 1HNMR (DMSO-d $\left.{ }_{6}\right)$ & $\operatorname{IR}\left(\mathrm{cm}^{-1}\right)$ & $\begin{array}{c}\text { MASS } \\
\text { EIMS }(\mathbf{m} / \mathbf{z})[\mathbf{M}]+\end{array}$ & $\begin{array}{c}\text { Melting Point } \\
\left({ }^{0} \mathrm{C}\right)\end{array}$ \\
\hline & 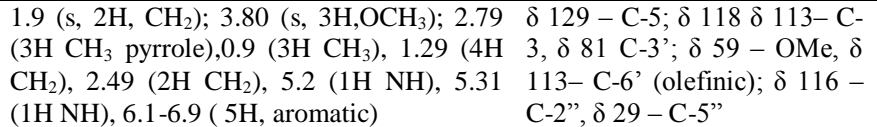 & $\begin{array}{l}1,648 \mathrm{~cm}^{-1}(\text { aromatic } \mathrm{C}=\mathrm{C}) .3343 \\
(\mathrm{~N}-\mathrm{H} \text { amide }), 2101(\mathrm{C}=\mathrm{C}), 3278 \\
(\mathrm{C}-\mathrm{H}), 1052(\mathrm{C}-\mathrm{O})\end{array}$ & $325[\mathbf{M}]+$ & $122-126$ \\
\hline
\end{tabular}

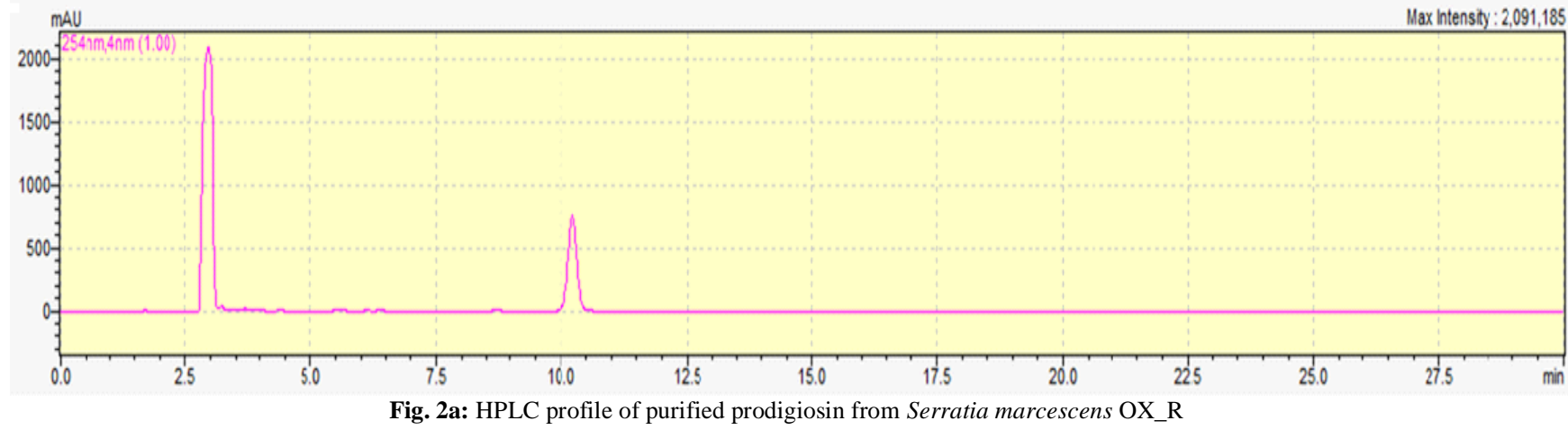<smiles>CCCCCC1=CC(C)=N/C1=C\c1[nH]c(-c2ccc[nH]2)cc1OC</smiles>

4-methoxy-5-[ (Z)- (5-methyl-4-pentyl-2H-pyrrol-2-ylidene)methyl]-1H,1'H-2,2'-bipyrrole

Fig. 2b: Structural elucidation of purified prodigiosin from Serratia marcescens OX_R 


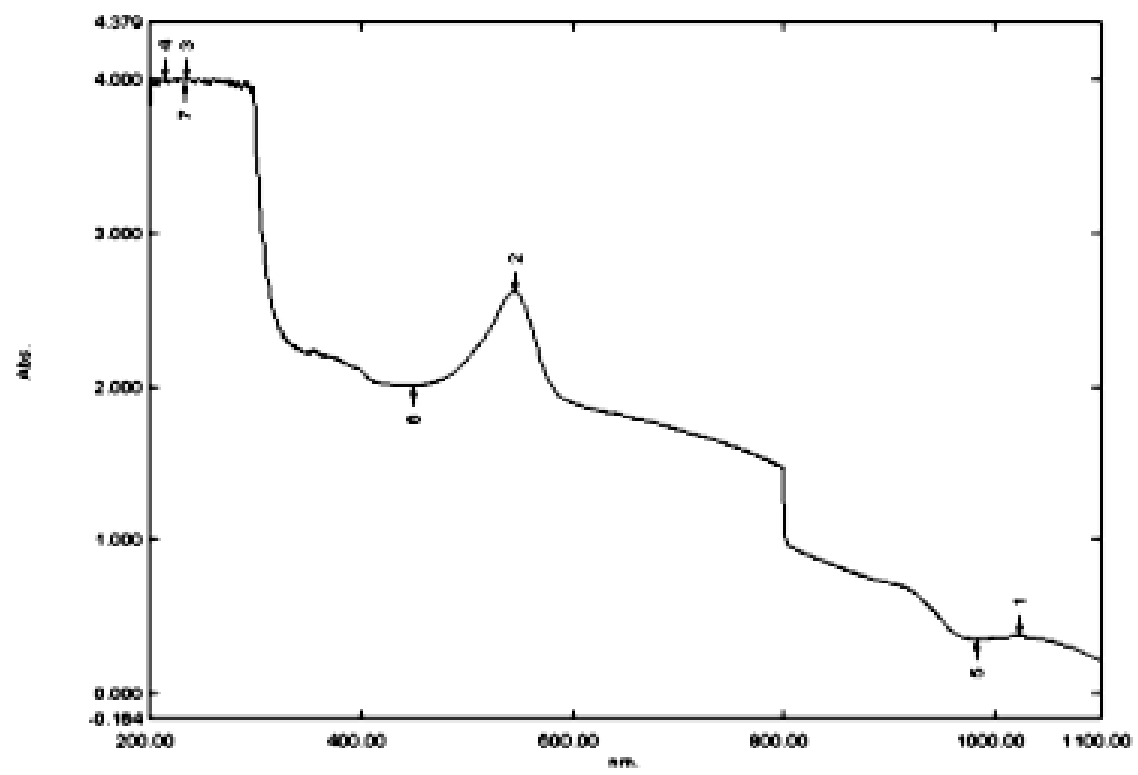

Fig. 3: Absorbance spectrum of prodigiosin produced by Serratia marcescens OX_R.

\section{Dyeing potential of prodigiosin}

Prodigiosin pigment has already been proved to have potential to dye cotton fabrics. Taking this into account, the harvested pigment was tested on cotton fabric as well as on latex material. Both the materials were observed to be stained with 100 $\mu \mathrm{g} / \mathrm{ml}$ pigment concentration. Latex material which was dyed by this pigment managed to retain the red pigment even after rigorous washing treatments with hot water and detergents. The ability of prodigiosin to dye latex has been previously reported (Liu et al., 2012). Prodigiosin has also been reported to efficiently dye polyolefins/polyethylene (Ryazantseva et al., 2014) indicating its capacity to be used as a colorant for non-fabric material.

\section{Prodigiosin acts as antimicrobial agent}

The antimicrobial potency of the prodigiosin against septic causing opportunistic skin pathogen Staphylococcus aureus NCIM 5021 was assessed in-vitro. The prodigiosin showed activity similar to the standard tetracycline and the effects seen were nearly equal to $100 \mu \mathrm{g} \mathrm{ml}^{-1}$ of tetracycline at agar well diffusion assay (Table 3).

Table 3: Antimicrobial activity of isolated prodigiosin

\begin{tabular}{llc}
\hline Sr. no. & Compound & Activity $(\boldsymbol{\mu g} / \mathbf{m l})$ \\
\hline 1. & Prodigiosin pigment HPLC elute & $2.5^{\#}$ \\
2. & Tetracycline & $0.2^{\#}$ \\
3. & Prodigiosin pigment HPLC elute & $100^{\$}$ \\
\hline
\end{tabular}

\#Minimum Inhibitory Concentration (MIC)

${ }^{\$}$ Equivalent to standard tetracycline

MIC described in Table 3 by pigment has 2.5 and by tetracycline were $0.2 \mu \mathrm{g} \mathrm{ml}^{-1}$ towards pathogen, similar to the results obtained for Serratia marcescens (Suryawanshi et al. 2014). Similar results were demonstrated by Lapenda et al. 2015 (Lapenda et al., 2015)against oxacillin resistant S. Aureus with
MIC $4 \mu \mathrm{g} \mathrm{ml}^{-1}$. Darah Ibrahim (Darah et al., 2014) have reported that prodigiosin is more efficient in inhibiting gram positive bacteria rather than gram negative bacteria.

\section{Docking and pharmacophore modeling studies}

The docking analysis was carried out to explore possible mode of action of the prodigiosin using biopredicta module of the V life MDS 4.3. Crystal structure Staphylococcus aureus DNA gyrase (PDB ID 2XCS) was utilized in the docking analysis. The Prodigiosin showed nice fit in the active site of the DNA gyrase and showed following interaction with the amino acids in binding pocket of DNA gyrase enzyme as shown in Fig. 4 and Table 4.

Table 4: Interactions of isolated prodigiosin with Staphylococcus aureus DNA gyrase.

\begin{tabular}{|c|c|c|}
\hline Sr.no. & $\begin{array}{c}\text { Type of } \\
\text { Interaction }\end{array}$ & Amino Acid \\
\hline 1. & $\begin{array}{l}\text { Hydrogen bond } \\
\text { Interaction } \\
\text { (Green color) }\end{array}$ & ARG53 \\
\hline 2. & $\begin{array}{l}\text { Hydrophobic } \\
\text { Interaction } \\
\text { ( Blue color) }\end{array}$ & $\begin{array}{llrl}\text { GLY351, } & \text { ILE34, } & \text { VAL165, } & \text { ARG54, } \\
\text { GLU162, } & \text { ARG53, } & \text { PRO50, } & \text { ARG45, } \\
\text { GLU43, } & & & \end{array}$ \\
\hline 3. & $\begin{array}{ll}\text { Vander } & \text { wall } \\
\text { Interactions } & \end{array}$ & $\begin{array}{lllr}\text { GLU43, } & \text { VAL44, } & \text { ARG45, } & \text { PRO50, } \\
\text { ARG53, } & \text { ARG54, } & \text { ILE153, } & \text { GLU162, } \\
\text { PRO163, } & \text { THR164, } & \text { VAL165, } & \text { ILE348, } \\
\text { GLY351 } & & & \end{array}$ \\
\hline
\end{tabular}

To identify key structural features which are responsible for antibacterial activity of the Prodigiosin the pharmacophore modeling is carried out in the mol sign module of $\mathrm{v}$ life MDS 4.3. Pharmacophore modeling showed features like Hydrogen bond donor, Hydrogen bond acceptor, Hydrophobic, Aliphatic, positive ionizable are important for antibacterial activity. The 
Pharmacophoric hypothesis indicates the two hydrogen bond donors (green), aromatic (golden), four aliphatic (brown) and hydrogen bond acceptor (blue) are important features for the activity as shown in Fig. 4.

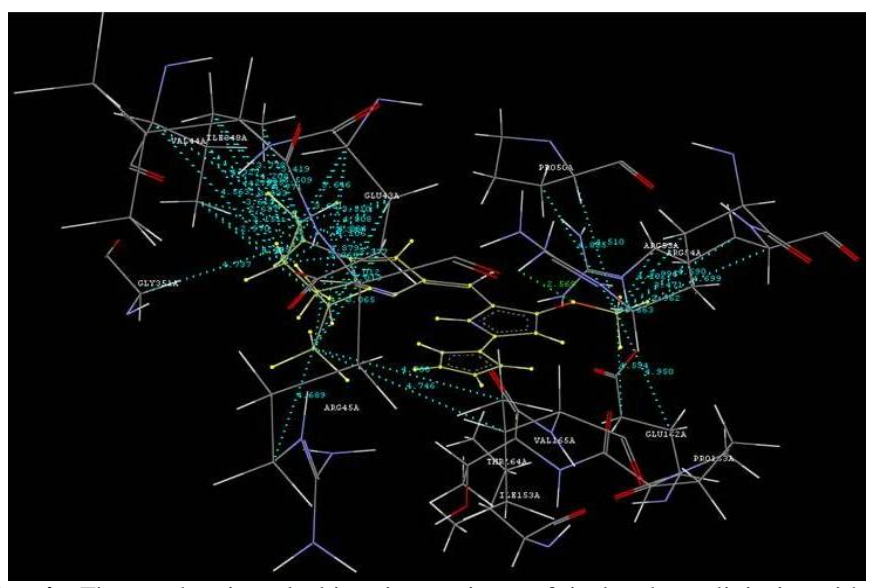

Fig. 4: Figure showing docking interactions of isolated prodigiosin with Staphylococcus aureus DNA gyrase molecule.

It is evident based on docking; prodigiosin could be a potential antibacterial agent against bacteria such as Staphylococcus and may exhibit blocking of DNA gyrase pockets. Pharmcophore modelling and docking analysis of Prodigiosin from Serratia marcescens have illustrated the potential of the molecule to inhibit various pathogens like HBV, HIV, Plasmodium vivax and $\mathrm{H} 1 \mathrm{~N} 1$ through protein-ligand binding (Suba et al., 2013). Bacterial DNA gyrase has been identified as an effective drug target owing to their specificity to affect only the prokaryotic system and not eukaryotic cells. A variety of natural products, small molecules and protein-based entities, have been identified as gyrase inhibitors. These are not generally directly usable as drugs, due to reasons such as toxicity and poor physicochemical properties, but they provide chemical diversity that is not readily achievable using chemical synthesis; they can also reveal novel modes of mechanism of inhibition of the enzyme (Collin et al., 2011). However, prodigiosin has found a range of applications in medicine indicating that unlike most of the natural products inhibitory to DNA gyrase, prodigiosin can be developed into an efficient anti-bacterial agent.

\section{CONCLUSION}

Pigment producer Serratia isolated from bat guano sample, is able to metabolize oxalate. Peptone glycerol broth supplemented with oxalate was found to be a superior medium for production of prodigiosin by Serratia marcescens. The prodigiosin showed good antimicrobial activity as compared to standard tetracycline against common skin pathogen Staphylococcus aureus. The docking analysis explored the possible mode of action of the prodigiosin against DNA gyrase enzyme of Staphylococcus aureus. The pharmacophore modeling studies showed features like
Hydrogen bond, Hydrophobic, Aliphatic, positive ionizable interactions are important for antibacterial activity. And hence substantiate the hypothesis that prodigiosin has the potential to inhibit the DNA gyrase protein, in fact evident based on fitness score values. The prodigiosin pigment also proved dyeing property on latex material. This study illustrates the potential of prodigiosin pigment isolated from oxalotrophic Serratia marcescens OX_R to be used as a dyeing agent for cotton and latex as well as antibacterial effect towards sepsis inducing Staphylococcus aureus. Based on these results we suggest that Serratia marcescens OX_R prodigiosin finds possibility of serving as functional basal substratum for septicidal drug development.

\section{ACKNOWLEDGEMENTS}

Financial support and sponsorship: Mangesh Suryavanshi and Nidhi Bharti were acknowledged Council of Scientific and Industrial research (CSIR-SRF) and University Grant Commission (UGC-DSK PDF) respectively for the research fellowships. Authors are thankful to the Department of Biotechnology (DBT), Government of India; Microbial Culture Collection Project (BT/PR10054/NDB/52/94/2007) for financial aids.

Conflict of Interests: There are no conflicts of interest.

\section{REFERENCES}

Alihosseini F., Ju K.S., Lango J., et al. Antibacterial colorants: Characterization of prodiginines and their applications on textile materials. Biotechnol Prog., 2008; 24 (3):742-747. doi: 10.1021/bp070481r

Bhadra B., Roy P., Chakraborty R. Serratia ureilytica sp. nov., a novel urea-utilizing species. Int. J. Syst. Evol. Microbiol., 2005; 55 (5):2155-8. doi: 10.1099/ijs.0.63674-0

Bravo D., Braissant O., Solokhina A., et al. Use of an isothermal microcalorimetry assay to characterize microbial oxalotrophic activity. FEMS Microbiol. Ecol., 2011; 78 (2):266-74. doi: 10.1111/j.1574-6941.2011.01158.x

Chang C.C., Chen W.C., Ho T.F., et al. Development of natural anti-tumor drugs by microorganisms. J. Biosci. Bioeng., 2011; 111 (5):501-511. doi: 10.1016/j.jbiosc.2010.12.026

Isaka M., Jaturapat A., Kramyu J., et al. Potent In Vitro Antimalarial Activity of Metacycloprodigiosin Isolated from Streptomyces spectabilis BCC 4785. Antimicrob. Agents Chemother., 2002; 46 (4):1112-1113. doi: 10.1128/AAC.46.4.1112-1113.2002

Collin F., Karkare S., Maxwell A. Exploiting bacterial DNA gyrase as a drug target: current state and perspectives. Appl. Microbiol. Biotechnol., 2011; 92 (3):479-497. doi: 10.1007/s00253-011-3557-z

Croft S.L., Seifert K., Duchêne M. Antiprotozoal activities of phospholipid analogues. Mol. Biochem. Parasitol. 2003; 126 (2):165-172. doi: 10.1016/S0166-6851 (02)00283-9

D'Aoust J.Y., Gerber N.N. Isolation and purification of prodigiosin from Vibrio psychroerythrus. J. Bacteriol., 1974; 118 (2):756-757.

Darah Ibrahim TFNJKS-H.L. Prodigiosin - an antibacterial red pigment produced by Serratia marcescens IBRL USM 84 associated with a marine sponge Xestospongia testudinaria. J. Appl. Pharm. Sci., 2014; 4 (10):001-006.

Gerber N.N., Lechevalier M.P. Prodiginine (prodigiosin-like) pigments from Streptomyces and other aerobic Actinomycetes. Can. J. Microbiol., 1976; 22 (5):658-67.

Giri A. V., Anandkumar N., Muthukumaran G., Pennathur G. A novel medium for the enhanced cell growth and production of prodigiosin 
from Serratia marcescens isolated from soil. BMC Microbiol., 2004; 4:11. doi: 10.1186/1471-2180-4-11

Gulani C., Bhattacharya S., Das A. Assessment of process parameters influencing the enhanced production of prodigiosin from Serratia marcescens and evaluation of its antimicrobial, antioxidant and dyeing potentials. Malays. J. Microbiol., 2012; 8 (2):116-122.

Gupta A.K., Dharne M.S., Rangrez A.Y., et al. Ignatzschineria indica sp. nov. and Ignatzschineria ureiclastica sp. nov., isolated from adult flesh flies (Diptera: Sarcophagidae). Int. J. Syst. Evol. Microbiol., 2011; 61 (6):1360-1369. doi: 10.1099/ijs.0.018622-0

Haddix P. Werner T. Spectrophotometric Assay of Gene Expression: Serratia marcescens Pigmentation. Bioscene., 2000; 26 (4):336.

Hassankhani R., Sam M.R., Esmaeilou M., Ahangar P. Prodigiosin isolated from cell wall of Serratia marcescens alters expression of apoptosis-related genes and increases apoptosis in colorectal cancer cells. Med. Oncol., 2015; 32 (1):366. doi: 10.1007/s12032-0140366-0

Ho T.F., Peng Y.T., Chuang S.M., et al. Prodigiosin downregulates survivin to facilitate paclitaxel sensitization in human breast carcinoma cell lines. Toxicol. Appl. Pharmacol., 2009; 235 (2):253-60. doi: 10.1016/j.taap.2008.12.009

Jenkins S., Incarvito C.D., Parr J., Wasserman H.H. Structural studies of C-ring substituted unnatural analogues of prodigiosin. CrystEngComm., 2009; 11 (2):242. doi: 10.1039/b813351d

Khanafari A, Assadi M.M., Fakhr F.A. Review of Prodigiosin , Pigmentation in Serratia marcescens. J. Biol. Sci., 2006; 6 (1):1-13.

Kobayashi N., Ichikawa Y. Separation of the prodigiosinlocalizing crude vesicles which retain the activity of protease and nuclease in Serratia marcescens. Microbiol. Immunol. 1991; 35 (8):607-14.

Krishna P.S., Vani K., Prasad M.R., et al. In -silico molecular docking analysis of prodigiosin and cycloprodigiosin as COX-2 inhibitors. Springerplus, 2013; 2 (1):172. doi: 10.1186/2193-1801-2-172

Lapenda J.C., Silva P.A., Vicalvi M.C., et al. Antimicrobial activity of prodigiosin isolated from Serratia marcescens UFPEDA 398. World J. Microbiol. Biotechnol., 2015; 31 (2):399-406. doi: 10.1007/s11274-014-1793-y

Lewis S.M., Corpe W. A. Prodigiosin-Producing Bacteria From Marine Sources. Appl. Microbiol., 1964; 12 (1):13-17.

Liu X., Wang Y., Sun S., et al. Strain for Enhancing Prodigiosin Production and Application To Textiles. Prep. Biochem. Biotechnol., 2012; 43 (3): 271-284. doi: 10.1080/10826068.2012.721850

Nakashima T., Kurachi M., Kato Y., et al. Characterization of bacterium isolated from the sediment at coastal area of Omura Bay in Japan and several biological activities of pigment produced by this isolate. Microbiol. Immunol., 2005; 49 (5):407-15.

Narendra Kumar P, Swapna T.H., Khan M.Y., et al. Statistical optimization of antifungal iturin A production from Bacillus amyloliquefaciens RHNK22 using agro-industrial wastes. Saudi J Biol Sci., 2015; doi: 10.1016/j.sjbs.2015.09.014
Patil C.D., Patil S. V., Salunke B.K., Salunkhe R.B. Prodigiosin produced by Serratia marcescens NMCC46 as a mosquito larvicidal agent against Aedes aegypti and Anopheles stephensi. Parasitol. Res., 2011; 109 (4):1179-1187. doi: 10.1007/s00436-011-2365-9

Pérez-Tomás R., Montaner B., Llagostera E., Soto-Cerrato V. The prodigiosins, proapoptotic drugs with anticancer properties. Biochem. Pharmacol., 2003; 66 (8):1447-1452. doi: 10.1016/S0006-2952 (03)00496-9

Ryazantseva I., Andreyeva I. Application of prodigiosin as a colorant for polyolefines. Adv. Biol. Chem., 2014; 04 (1):20-25. doi: 10.4236/abc.2014.41004

Sahin N. Isolation and characterization of mesophilic, oxalatedegrading Streptomyces from plant rhizosphere and forest soils. Naturwissenschaften, 2004; 91 (10):498-502. doi: 10.1007/s00114-004$0562-4$

Shahitha S., Poornima K. Enhanced production of prodigiosin production in Serratia marcescens. J. Appl. Pharm. Sci., 2012; 2:138-140

Suba K., Stalin A., Girija A., Raguraman R. Homology modeling and docking analysis of Prodigiosin from Serratia marcescens. Biotechnology, 2013; 55:12897-12902.

Suryavanshi M., Hingamire T., Shaikh N. In-vitro inhibitory activity of cow urine with Helicteres isora Linn. Fruit extracts against copper resistant Xanthomonas sp. IJPRD, 2014; 974 (6):70-75.

Suryawanshi R.K., Patil C.D., Borase H.P., et al. Studies on production and biological potential of prodigiosin by Serratia marcescens. Appl. Biochem. Biotechnol., 2014; 173 (5):1209-1221. doi: 10.1007/s12010-014-0921-3

Sukumaran C.P., Singh D. V., Mahadevan P.R. Synthesis of Lasparaginase by Serratia marcescens (Nima). J. Biosci., 1979; 1 (3):263269. doi: 10.1007/BF02716875

Wang S.L., Wang C.Y., Yen Y.H., et al. Enhanced production of insecticidal prodigiosin from Serratia marcescens TKU011 in media containing squid pen. Process. Biochem., 2012; 47 (11):1684-1690. doi: 10.1016/j.procbio.2011.07.010.

Worthington R.E. I Oxalyl amino acid anhydrides II Pigments of a Serratia marcescens mutant. Retrosp. Thesis. Diss. Paper., 1962; 2032 .

\section{How to cite this article:}

Suryavanshi MV, Waghmode SR, Bharti N, Choudhari PB, Hingamire TB, Shouche YS. Isolation and virtual screening of antimicrobial prodigiosin pigment from oxalotrophic Serratia marcescens OX_R strain. J App Pharm Sci, 2016; 6 (11): 052-058. 